\title{
MEDITATION AS THE NON-MEDIATED PERCEPTION
}

\author{
Victor F. Petrenko, \\ Vladimir V. Kucherenko \\ Lomonosov Moscow State University \\ Moscow
}

Authors discuss notable philosophical and psychological aspects of Buddhism and Hinduism, as well as different features of meditation techniques in their relations to psychological study of consciousness.

Keywords: consciousness, Buddhism, Hinduism, meditation, categorization, decategorization.

The ways of God are inscrutable and consciousness of people traveling in mental spaces and divided by the distance, time, culture, and religion are likely to meet and even merge, resonating by similar emotional-imaginative experiences against "eternal" problems, objects, and thoughts.

Concentrating "here and now" on the view of the majestic mountain ridge or looking at the horizon of the great ocean, we experience states close to the ones experienced by another person standing here and wrapped up in contemplation centuries ago. At this instant of time the past and the present, as well as the future (in perception of a person, who is not born yet) run into one another, and we feel the abyss of eternity. This is a feeling of a person facing the incredible, similar to the feeling of a sailor from the sailing fleet, who stands on the ocean shore (peering into the sea distance) and misses lands - dangerous and alluring - that are not discovered yet. In ancient Chinese short stories these resonant mental states could serve for literary characters as channels for traveling in space and time (Nu Sen-Ju, 1970).

The research is made under the financial support of Russian Foundation for Basic Research, grants No.05-06-80510a and No.07-06-10045K. 
The poetic line of a long since dead poet, as an abscissed leaf of the autumn garden awakens thoughts about the evanescence of genesis and recollections about the feast of the gone summer, and for a while we become this poet, live his feelings.

The task of this article - is to arouse and interest of Russian psychologists and psychotherapists to meditative practices of the Buddhism and Hinduism, giving, in our opinion, the invaluable experience of touching the infinite and studies of which are the inexhaustible fountain of psychological knowledge. Western psychologists, beginning with C.G. Jung (Jung, 1997; Moacanin, 2004) and continuing in the persons of leaders of the transpersonal psychology: S. Grof (2002), A. Mindell (2004), K. Wilber (2004), R. Walsh (2004) have already got in touch with the fathomless depth of these studies, and took a lot into their own practices and psychotechnics. In the Russian psychology there are also bright researchers (Kozlov \& Maikov, 2000; Kozlov, 2006; Karitsky, 2002; Lobzin \& Reshetnikov, 1986; Volkova, 2002; Ozhiganova, 2002), working in resonance with Buddhist experts. In humanitarian areas of studying culture and history related to psychology there is a deeply rooted tradition of the Russian school of studying Buddhism, represented by works of S.F. Oldenburg (1994), O.O. Rosenberg (1991), F.I. Scherbatskoy (1988), N.V. Abaev (1989), G.M. Bongard-Levin (1980), B.D. Dandaron (1997), A.M. Piatigorsky (2004), G.T. Tsybikov (1991), and continued in the work of the Institute of Oriental Studies of the Russian Academy of Sciences (V.N. Androsov, 1990), Institute of Oriental Studies of Saint Petersburg branch of the Russian Academy of Sciences (E.A. Torchinov, 2005; V.I. Rudoy, 1990), Institute of Ethnology and Anthropology of the Russian Academy of Sciences, Institute of Mongol, Buddha, and Tibet Studies of the Siberian branch of the Russian Academy of Sciences (A.A. Bazarov, 1998; S.Yu. Lepekhov, A.M. Donets, and S.P. Nesterkin, 2006), Saint-Petersburg University (A.V. Paribok and V.G. Ehrman, 2003).

This article is not a systematic research of a certain psychological problem within the framework of the Buddhism philosophy. It is also not a certain guide or glossary interpreting ideas of Buddhist mentality to the language of the modern psychology. It is not even a summary of books on philosophy and psychology of Buddhism that we have read. More likely, the genre of this article can be characterized as the response of consciousness of modern psychologists of the beginning of 
the 21st century, whom we actually represent are, to the experience of comprehension of the Buddhist mentality, overlaid on our internal experience of work in the altered states of consciousness. This experience of comprehension of the Buddhist mentality includes both the experience of communication with Buddhist lamas that we acquired within the framework of the expedition of our laboratory members "Communication psychology and psychosemantics" of psychology faculty in MSU, in summer 2006-2007 to Buryatia ${ }^{1}$ and Tuva to the Buddhist datsans, and the knowledge scooped out of Sutra and Shaster - canonical Buddhist texts.

This article is dedicated to the description and analysis of the similarities of a number of Buddhist meditative practices and modern psycho-therapeutic methods, related to the work with images. These psychotechnics that appeared in different epochs in the Buddhist and Christian cultures have, in our opinion, similar psychological mechanisms and close phenomenology that we strive to show in this publication.

Our text, where Buddhist parables alternate with cases and examples from the modern psychotherapy, and the Buddhist terminology adjoins with Christian notions, can be perceived as eclectic. But we have chosen this style of narration in order to show by the network of associative connections and making analogies that the variety of cultural artifacts and "diversity of the religious experience" (James, 1993) hides a number of unified core psychological phenomena, which can be successfully investigated by the science of psychology. This publication is considered to make modest steps in this direction. It is dedicated to the practice of work with images and to the change of basic notional orientations of a human in the course of meditation and hypnotherapy.

Origins of meditative practices date back to the dateless antiquity of the Vedic culture of India. But they were mostly developed in the Bud-

\footnotetext{
1 The authors would like to thank the following Buddhist lamas for communication, comments and valuable remarks: Eshe-Lodoj Rinpoche, Khambo-lama Damba Ayusheev, lama Choi-Dorji Budaev, Dogba lama, Rigzen lama, Danzanjama lama, lama Grigoriy, student Erdeni, doctors, specialists in the sphere of Tibetan medicine: Karatuev N.K., Krupsky M.A., Dygzhima Ayushev, orientalists: academician of RAS G.M. Bongard-Levin, V.N. Androsov, scientists buddhologists of the Mongol, Buddha, and Tibet Science of the Siberian Branch of RAS: Corresponding Member of RAS B.V. Bazarov, professor S.Yu. Lepekhov, S.P. Nesterkin, Cand. Sc. Philosophy Dulma Ayushev, buddhist S. Kornilov.
} 
dhism and Hinduism. For the purposes of distraction from the vanity of this world (samsara) and sufferings caused by the affection thereto, as well as for the disciplined mind and concentration of attention on transcendental objects Buddhists have worked out many practices of work with consciousness and its altered states, and introduced notions describing these states. Consciousness was broadly interpreted by Hindu, who referred to it perception, and thinking, and memory. In this context, though historians think that psychology as science appeared in the 19th century and connect it with the appearance of the first psychological laboratory founded by $\mathrm{W}$. Wundt, this date refers only to the appearance of the experimental positivist, branch of psychology. But the empirical study of consciousness and its altered states, a wide use of psychotechnics was in common practice in the Hinduism and in the practice of yogis, and presumably beginning from 5-4th century B.C. - in Buddhism. These practices and their "theoretical part" were carefully described in the form of sutras (texts, paraphrasing of Buddha's ${ }^{2}$ words by his closest followers) ${ }^{3}$ and Shasters (ethics-philosophical tractates) and where, as a rule, the line (the chain) of knowledge devolving was recorded by name, because the practices were mastered under the leadership of a teacher, and the direct line of succession was important from the competent, en-

2 "It is well known that within centuries the Buddha was honoured or is still honoured in India, in the central Asia, Tibet, China, Mongolia, Korea, Japan, on Ceylon, in Burma, Indo-China, Indonesia, in a number of Siberian regions, in Kalmykia. It is less known that as a saint the Buddha penetrated the Christian, Manichean, Zoroastrian, Moslem religion in the end of 16th century already. Under the name of the saint Jehoshaphat he appears in Roman martyrology. On November, 19th, the Orthodox Church commemorates the memory of Josaphat, the Indian prince, together with the memory of the Reverend Barlaam. Dissenters and wanderers sang in Russia about them and, first of all, about Josaphat the Beautiful" (Toporov, 1991, p. 68).

3 Buddhism appeared in India, presumably in 5 or 4 century B.C. and communicated in the oral Tradition (form). The earliest written texts date back to $3 \mathrm{~d}$ century B.C. While in Mahayana the state of Buddha (Buddhism) turns into the highest universal principle, any monk or yogi who experienced the state of awakening, the verity of which inherently is immanent and self-evident, could consider his understanding and his vision as the understanding and vision of Buddha, and record them in traditional forms of sutra testifying that this "text is the true words of Buddha." As E.A. Torchinov writes, referring to remarks of the nameless buddhologist: "Buddha, five hundred years after his death delivered more speeches and sermons than for his whole life" (Torchinov, 2006, p. 91). 
lightened teacher. ${ }^{4}$ (A teacher in the Sanskrit language - "guru," and in the Tibetan language - "lama"). Particularly it concerned "aboriginal" texts, i.e., owned by Buddha Shakyamuni (the civil name of whom was Gautama Siddhartha) and his direct followers, the great Arhats and Bodhisattva. Generally, the development of the Buddhist literature was as a collection of remarks to aboriginal texts, comments to remarks, etc.

The study of the psychological succession of the Buddhism has a deep theoretical significance, because the main and even the only object of the Buddhist interest was the problem of conscience and the conceptual thesaurus of Buddhist study dedicated to the conscience admittedly exceeds the conceptual dictionary of the modern psychology. But it is not less important the psychotechnic experience of the Buddhism, within the framework of which effective methods of psychological trainings and mental self-regulation have been elaborated. It can be said that Buddhism is extremely "practical" and "pragmatical." "Buddhism claims that each person is potentially able to pass from the state of suffering to the state of the complete serenity, the complete rest, the penetrative wisdom, by means of own conations and practical actions. That is why the central place in the Buddhist concept of 'saving' from worldly mistakes and sufferings was occupied by study about achievement of the state of 'enlightenment' or 'awakening' that became the highest soterological aim of all Buddhist schools. And this conditioned in Buddhism the important meaning of not merely of the 'theory' of achievement of the 'enlightened' state, but also the practical methods of changing the original moral-psychological state of a human" (Abaev, 1991, p. 5).

What was posed by the domestic psychologists as the most important task in the beginning of the revolutionary 20th century - namely,

\footnotetext{
4 Along with the transfer of knowledge from a teacher to a pupil in the form of a chain ascending to Buddha himself, there is a practice of concealment or secret knowledge in Mahayana (see Tulka Tondub Rinopche, 2006), which was practiced by the founder of the Buddhism in Tibet - the guru Padmasambhava. Followers of the Ningma school honour him as the second important teacher after Buddha. Upon instructions of the Guru Padmasambhava, in splits in rocks, caves, a lot of fragments of canonical texts (socalled "terma"), which are used after centuries as keys for recovery of memories about the study. The enlightened meditating person ("terton" in the terminology of Mahayana), entering the modified states of the conscience, is able to recall the full text of the study. One recollects immediately the insight of Plato about the study as a recollection, and Bulgakov's: "manuscripts do not burn."
} 
the formation of "a new person," with other aims, was performed by Buddhist teachers with a great success two and a half thousand years ago. So, Buddha Shakyamuni can be considered the founder of psychology as the experimental - empirical science about consciousness, thus shifting the dates of appearance of psychology by two and a half thousand years back, though, of course, the origins of meditative practices are rooted in more ancient past (see Androsov, 2001).

It is worth reminding that Buddha - is not the personal name and not the title. Buddha - is the one who achieved enlightment and is in the state of nirvana. (The Sanskrit word "nirvana" originates from the root "nirva" meanings to calm down, to go down as a lamp or as the sun at dawn). Psychologically, nirvana - is a particularly altered state of consciousness, characterizing the internal calm, removal of the duality (separating oneself in the world), feeling of integration with the infinite space and experiencing the unity with the whole world of the animate and inanimate nature. In our opinion, the completeness of this state was expressed by the Moslem mystic al-Hallaj ${ }^{5}$ (i.e. a person, who practices quite a different religion) in the statement: "I am God," who was executed for this as for the blasphemy. Thought this statement can be interpreted as the greatest resignation, refusing his own "self" in any subjectness and completely dissolving ego in the God. It can also be considered as the apotheosis of solipsism, leaving for "I" - the subject of perception and cognition - the role of the only demiurge. These could be either words of a Hindus, who experienced the unity of confluence of oneself and the God, dilution of "I" (Atman) in the Absolute (Brahman). The enlightened, i.e. Buddha, being in the same state of non-duality (non-promi-

\footnotetext{
5 "The fate of one of the greatest Sufis, al-Hallaj, reminds the fate of Christ. Hawing experienced the feeling of the unity with God, he spoke thereof openly. Keepers of the law regarded it as the blasphemy. Al-Hallaj was executed in Baghdad in 922. They lashed him in public, cut off his hands, hung him head down, lapidated him, and in the end they decapitated him and burned his body (so it could not revive on the Judgement day). The fury of the true faith keepers was aroused by the fact that al-Hallaj openly neglected customs, rules set by the Koran. When he was asked, whether it was necessary to pilgrim to the Mecca, he answered: "Walk around me - there is God inside me too." Sometimes in the state of ecstasy he uttered the words reminding the evangelic ones: "I am the truth." For the religion of the fear of God - this was the unbearable blasphemy" (Pomerants \& Mirkina, 2006, p. 101).
} 
nence oneself and the world), would deny any categorization, keeping the "generous silence."

Usage of altered states of consciousness (and, as a consequence of this, accumulation of the working experience with the conscience states) is inherent not only in Buddhism, but also in other religions. Altered states of consciousness are achieved by different psychotechnics - from fasting, meditation and a prayer, sensor deprivation (seclusion) to dynamical meditations (utterance of mantras, carved on a rotating prayerful drum of Buddhists; circular dancing movements of dervishes in Sufism; rhythmical swinging of praying Judaists, shaman dances and ritual dancing of Africans, bacchanalia ecstasy of ancient Romans and the ritual sex of Tantrists in India). In Christianity the contemplating of saints, the Virgin Mary or visions of Christ martyrs have been repeatedly described in the religious literature (for example, visions of Saint Teresa or Juan de la Cruse in the Catholicism) and were considered not as the consequence of the personal activity of a believer (which is not welcomed by the Christian church), but as the form of grace, when a saint himself appears before a human.

In the New time within the framework of the European science the line of succession of the work with altered states of consciousness can be drawn from Paracels (T.B. von Hohenheim), F.A. Mesmer, the abbot Faria, M. Brad, marquis de Puységur, J. Charcot, G. Bernheim, V.M. Bekhterev to a so-called Erickson hypnosis (Erickson, 2006).

In the classical hypnosis the monotony of a hypnotist's (a suggestor's) speech sound, fixation of patient's eyes on a visual excitatory (or on pupils of the suggestor) cause - by virtue of monotonia and tiredness of receptors, inhibition of the second signaling system (in terms of I.P. Pavlov) and falling into hypnotic state. (Hypnosis in Greek - a sleep.) The Erickson hypnosis is based on the work with imaginations or, so-called secondary images, i.e. images of objects, which are not directly viewed, but excited by the power of imagination and, unlike the classic hypnosis, is connected with the internal or external activity of a patient. (Typological phenomenology of images is presented in the work of A.A. Gostev, 1998.) The work with secondary images can be illustrated by the example of bringing a patient into the trance state in the Erickson style: a patient is asked to imagine something very familiar, for example, his own room, and to describe the location of the furniture in the room, the color of wallpapers, blinds. Thus, the attention of a patient is switched from ex- 
ternal objects of perception to internal ones, caused by the force of recollection and imagination of a view. In this way, the secondary (or mental) visual patterns become actual. Fulfilling the instruction of a suggestor, a sort of detaches himself from the present situation in his imagination, and only a slight push is required to bring his attention to the imaginative (illusory) world completely. For example, they tell him: "and now the evening is at hand, the light in the room is growing dim, you put out a candle (a newly introduced illusory object) and see vibrating shadows of objects projecting on a wall." I.e., not only images drawn from the memory appear in his imagination, but also created by the imagination. Deeper and deeper a patient sinks into the illusory reality. Then the method of Erickson hypnosis is used, called by Erickson as "the junction point of modalities," enabling to add a visual pattern with sound and kinesthetic components. For example, asking a patient about the presence of table or wall clocks in his room, a suggestor draws his attention to the sounds of clockwork. The patient begins "hearing" ticking of the clocks. There and then, watching "swinging" of blinds because of the air movement, the patient begins to feel the coolness of the wind from the street, and "looking out" of the window on a road, where cars are passing by, the subject (the patient) "hears" their movement and "inhales" the street smell. Such form of bringing a subject into a trance state by an experienced suggestor can be twisted with an ordinary conversation and is badly reflexed by a patient.

At that, we would like to point out that trance states do not represent something extraordinary in our life, and the absorbing watching of a feature film, identifying oneself with characters, also gives an example of a trance state, different from the Erickson hypnosis by the depth of involvement.

But let us return to Buddhism. The proximity of western psychotherapy methods to the Buddhist psychiatric practice (mainly received "through second hands" indirect cultural borrowings) was noted by C.G. Jung, acknowledging that his way of "comprehension of the world of the Buddhist thought was not in the direction of studying the history of religion or philosophy. It was a professional interest of a doctor, whose duty - is to ease sufferings of a human, that I became acquainted with views and methods of Buddha, this great teacher of the mankind, induced by the sense of sympathy to people, doomed to the old age, illness and death" (as cited in Albedil, 2006, p. 30). 
Notwithstanding that the experience of being in the altered states of consciousness is peculiar to practically all religions, the deliberate and purposeful activity on voluntary entering a trance state through the meditation, through the retreat (a form of solitude for the purpose of spiritual practice, virtually close to the orthodox "seclusion"), through breathing practices and yogic asana is peculiar, nevertheless, exactly to the inflorescence of Indian religions: Brahmanism, Hinduism, Jainism, and certainly, Buddhism that has a number of branches as well: Hinayana, Mahayana, Vajrayana that, in their turn, have a number of branches: Kagyu school, Nyingma, Dzogchen, Sakya, and Gelug (which Dalai Lama belongs to). The main difference of Hinayana - Small chariot (yana - in Sanskrit - a chariot) from Mahayana - (Grand chariot) is that the final aim of Hinayana - is achievement of arhat state, lying in the personal liberation-enlightenment and approaching of nirvana, breaking a circle of samsara and interrupting a chain of karmic births. "That who wandered, cheerful, free in every respect, who threw off all bonds has no fever of passion. His lot - is the liberation, free from wishes and conditions. His path, as that of birds in the sky, is difficult for understanding. His feelings are calm like horses harnessed by a coachman. He denied pride and is deprived of wishes. Even gods envy him" - this is how Dhammapada the great book of Buddhism, characterizes arhat (1991, p. 18).

The practice of Hinayana (18 schools) is also called Theravada, meaning "study of the oldest" in the Pali language, and its canonical texts include, in particular, Tripitaka ("three baskets of study"). Theravada is more connected with the southern area of the Buddhism, and Mahayana - with the northern and the Far-Eastern.

The goal of Mahayana - is the achievement of Bodhisattva state (bodhi - the awakening, sattva - the creature), i.e. the creature, who has reached the enlightenment, but who has not reached the nirvana, as the form of liberation from the cycle of births, but out of the sense of sympathy continues the practices for the good of all living beings and bringing learning to people. In this context, Mahayana is brought closer to Christianity by the position of love and sacrifice. However, there are fundamental differences. In Christianity it is underlined that "the belief without actions is dead" and besides prayers, penance, fast, and so on, active actions in the world are required from a believer (especially in the Catholicism and the Protestantism), help for sufferers and the needed, as 
well as the participation in the charity. But Buddhism is much less active, so to say, in the social context, and the accent is made to the transfer of learning (i.e. to the enlightenment of a human) and to the work in the form of meditation in the mental context. The idea of the world duality (ideal and material) is not peculiar to the Buddhism, ascending to platonics and the Old Testament, and a thought is assumed just as efficient as a deed. That is why, for example, the meditative technique of "collection and delivery" (see Elo Rinpoche, ${ }^{6} 2006$ ), when meditating absorbs sufferings and misfortunes of the others in the form of a black light, and gives back good energy to the sufferers in the form of a golden shining, is considered as quite an efficient psychiatric practice of the world harmonization.

Both the texts of Theravada, and the books of Mahayana contain the detailed description of meditative methods, which can be brought to two main directions (see Bhikku Kvantipallo, 2005):

1) Samadhi (or Shamatha) - the path of serenity and calmness, and

2) Vipassana (or Vipashiana) - the path of insight and realizing wisdom, transcendental analysis and intuitive contemplation.

Samadhi is achieved by the concentration of attention and interruption of a chain of verbal associations and thoughts ("stream of conscience" - according to James). Shraddhotpada-shastra gives the following description of meditation: "If anyone wants to practice shamatha, he should dwell in a calm spot, sit straight, putting thoughts in order (i.e., concentrating them in one point. - N.A.). His attention should not linger on what he sees, hears, senses or knows. All thoughts, as soon as they appear, should be thrown away, and even the thought of extirpating thoughts should also be driven away..." (as cited in Abaev, 1991, p. 25). Other techniques of thoughts calming down are connected with the narrowing of consciousness, its fixation not on conceptual forms, but on immediate senses, coming from sense organs. For example, the practice of many days fixation of attention on the walking, including the continuous perception of each movement or concentration of attention on the process of inhaling and exhaling, leads to narrowing of $\mathrm{c}$ consciousness, and then to passing to its altered forms. I.K. Shetok, who had been on a three-week practice to a special course of submergence into the meditative state (the course of satipatthana) for mind upbringing. It was worked

6 "Rinpoche" is not a proper name, rather a title. 
out on the basis of ancient practices by Buddhist priest Mahasi-sayado in the Center of Saasan Iita in Rangun (Burma). He describes such continuous concentration of attention within the whole course: "While walking, one should hold attention on the movement of each foot as it rose, moved forward and went down on the floor or on the ground; each of these walking movements had to be accompanied by the mental repetition of words 'up', 'forward,' 'down'.. During each step one should not let oneself distract the attention from the movement of feet. Each time, having walked a required distance, it was necessary to shift the attention in order to stop, turn and begin walking again... Each time, when the mind deviates from its object, then the attention is drawn by something external, it is necessary to bear this fact in mind and softly, but emphatically return it to the subject of contemplation... Soon my life turned out to be dependent on a monotony routine - walking, sitting, and walking again. And in this process something that was bound to happen inevitably happened - the outer world began to move away from my conscious thoughts" (Shetok, 1994, p. 33). The aim of a Buddhist, - writes Shetok, who undertook a course of satipatthana, - is to acquire vipasan or enlightenment. Only when mind is calm, the enlightenment of intuition can get access to feelings underlying Buddhist doctrine. They appear spontaneously in the consciousness as visual images or as extremely truthful plots, reminding parables.

In hypnotic sessions (shorter), where the concentration of a patient's attention is facilitated with the help of a suggestor, it is practiced the fixation of attention on the weight of arms, on constrained body and its further "dilution" in the space. The concentration of attention leads to the stop of consciousness flow, and a patient, as a rule, perceives the uniform, homogeneously colored space, the color of which, evidently, is determined by the emotional state of a patient.

In the orthodox practice of Hesychasm (see Khoruzhy, 2005) the practice of mind "soberness" is used (in essence - meditative): “... Those who wish to belong to themselves and to become authentically 'monks' (indivisible) according to the inner man, it is obligatory to bring the mind inside the body and to hold it in there. While those who have just started struggling have a jumping mind, and they have to return it back again, but it slips away from inexperienced ones, who do not know yet, that there is nothing more difficult-to-catch and flying-away than their own mind, then some advise to watch closely the inhale and exhale, and to 
hold breathing ${ }^{7}$ a little while watching it, as if holding the breathing and the mind, until, reaching the highest steps with God and making one's mind nonwandering and pure, free templars would not learn to concentrate it strictly in the 'unified convolution." (Palama, 2005, p. 47-48). After "the highest ascent we - citing Palama Deonisiy - unite with inexpressible." Concentrations of attention on the heart of a $\operatorname{prayer}^{8}$ causes a flow of intensive white light interpreted by isihasts as the emanation of the divine energy ("The Light of the Mount Fabor").

On the background of perceiving the color space or a flow of light, the meditating can experience spontaneous feelings in the form of movement inside the energetic flows, traveling into unusual, difficult to describe by the natural language, worlds, etc. During sessions of hypnotism these can be both spontaneously appearing pictures from the past of a patient, images of great places, feeling oneself in the form of a free flying bird or a powerful animal, or even a drop of rain sparkling in the sun, rolled down on a green leaf.

In Tantric practices of vipassans ${ }^{9}$ the meditation is usually directed on a certain object, the so-called Yidam. This is a male's or a female's enlightened being, which is visualized by the practicing, and whose mantra is continuously repeating for the purpose of identification with yidam, to gain his inherent state of consciousness (mind). Identifying oneself with yidam, the practicing gains different, inherent for this deity siddhi (abilities), such as the gift of clairvoyance, medical treatment or a mental shift in space. As a yidam can be an image of a direct teacher, Amitabha

7 Here Grigory Palama refers to the composition of Semion New Divine: "The method of a sacred prayer and attention to oneself."

8 The heart charkas (anahat) in terminology of the Hinduism and the theosophy.

9 The Tantric Buddhism (Vadzhrajana or Diamond chariot) and the school of yogochara became the leading directions of the Mahayana Buddhism in India on the eve of its sunset (8-12 $2^{\text {th }}$ centuries) (caused mainly by Moslem conquests of the India north), and in such form the buddhism was borrowed by the Tibetan tradition, and through it penetrated to Mongolia, Buryatia, Tuva, Kalmykia. (The Tantric Buddhism is presently distributed in the Christian West as well - see Ayusheva, 2003). Tantras (i.e. doctrinal texts) of Vadzhrajana affirm that due to complex liturgy, the effective practice of mantras and visualization of deities images (yidams), as well as the contemplation of mandals, it is possible to achieve the state of Buddha within one human life. The following examples of the Buddhist practices, described by us, will mainly concern the Tantric Buddhism of Vadzhrajana. 
(Buddha - personification of wisdom), and such great bodhisattvas as Avalokitesvara (personification of sympathy), Manjushri (personification of evanescent knowledge), Vajraapani, White and Green Tara. ${ }^{10}$ In Tantric Buddhism, spread, in the first place, in Tibet and distributed by Tibetan teachers all over the world, meditative practices are accompanied by mantras and mudras.

Mantras - are sound symbols (for example, OM MANI PADME HUNG - is the mantra of Avalokitesvara, or OM MUNI MUNI MAHA MUNIE - mantra of Buddha Shakyamuni), having sacral meaning (Jampa Tinlay, 1995, p. 23). In themselves mantras can have no certain verbal meaning, but the character of a sound pattern, in virtue of "a sound symbolism," creates some emotional spirit (connotative meaning). The rhythmical iteration, melodiousness of mantras, similar to music, creates the mood, raises the spirit of a meditating. Besides, long iteration of one and the same syllable stops the flow of verbal conscience, verbal associations and contributes to bright visualization. By the example of mantras, the significant difference of such forms of the changed conscience, such as the meditation and the prayer, should be noted. Mantras ("words" of meditation), in the course of repeated reiteration are desemantized. Nothing should disturb the mirror-like surface of the meditative rest, no emotion should cause the excitation of this universal state, as the saying goes, "nothing personal." As a mountain pure lake, the state of meditation reflects the unfathomable depth of sky. Consciousness of a human is resonant to the impersonal Absolute.

In the first place, a prayer - is a form of communication to the personal God, a request (entreaty) for help, expression of love to God. It is emotionally (mentally) and spiritually saturated to the limit. "The best prayers, - writes F.E. Vasilyuk, - are the fruit of inspired poetic expression of mental-spiritual states, which have been once experienced by a saint, i.e. a spiritually-genius human, and have taken a beautiful form. As in a line by Pushkin 'I recall a wonderful moment,' how many times it is repeated, it lives fadeless, the trembling of amazement of a loving look, so in words of a prayer the live prayerful sense of the saint has crystallized, and when a person warms this prayer with his breath, his sincerity, it starts pulsing and responding. Aspiring to express one's personal

10 The White and Green Taras - female deities, who were born, according to the legend, from tears of Buddha. 
by means of this prayer... a person finds the possibility to absorb from words and images of the prayer the mental and spiritual experience of holiness, resignation, penance openness, and so on, to include it in his experience, to learn, to enrich the experience by the same spiritual and creative movements, which the saint's spirit made under the action of the grace and the prayerful impulse" (Vasilyuk, 2005, p. 44).

Mudras - the ritual symbolic gestures (resembling figures, formed by fingers of hands of Indian dancers). Mudras have a symbolic meaning, resonant to one or another state of consciousness. In our opinion, mudras perform the same function of a stimulus, reflexively causing a necessary reaction, as "anchors" 11 in the Neurolinguistical programming (Bandler \& Grinder, 1995). But unlike the "anchor," which can be any external stimulus in NLP (touching, sound, pose of a suggestor), mudras have the fixed, sanctified by a ritual, poeticized symbolic meaning, assisting meditating to achieve the highest states of consciousness.

Smell of fragrances, activating connected with the "emotional brain" (including the hippocampus, the limbic system, areas of the hypothalamus, forming a circle of Papets - according to A.R. Luria, 1968) subcortex zones; music, accompanying meditation, bringing us beyond the meaning of words and submerging us into the state of the intuitive perception; rhythmical strokes of a drum and a gong, supporting (activating the reticular formation by abrupt sound stimulus) high level of attention - all this contributes to the exit of consciousness from the routine reality into its altered states (see Kucherenko, Petrenko, \& Rossokhin, 1998).

In meditation on yidam "the meditating is offered a deity, chosen in accordance with his needs and his certain spiritual abilities. He is asked to devote all his attention to the form of the deity, which he should create

11 Anchor - is a stimulus launching a conditioned reflex reaction of a patient, with the help of which a suggestor (or the patient himself) can control the conduct of the patient. For example, the patient, who suffers from obsessive fears, is convinced that when he touches the earlap of his ear - horrible images would disappear. The established conditioned reflex bond gives the possibility for a patient to control his states. The technique of anchoring can be used for manipulating of a man too, for example, by means of mass communication. So, an announcer or a political correspondent informs current news pleasant for the TV audience, being in the right part of the screen, and non-pleasant - in the left. Then he tells about the biography of some political leader, about whom would like to form a favourable opinion, sitting in the right part of the screen, and shifting to the left party, when commenting actions of a personage rejected by him (or a customer). 
in his mind. The smallest details of this image in all its complexty and in all its colors shall visualize in such a way, that the image becomes as real as the practicing himself. Certainly, the practicing not merely contemplates this deity, he identifies himself with it, as if being this deity. At this moment he transforms into the deity: the archetypical substance of the deity is passed on to him. The core of visualization is in this unity with the deity. We are speaking of the dynamical process, where the ego of the meditating, his usual state is abandoned and is changed with the highest conscience of the deity. Using the terminology of Jung one can say that the ego of the individual was sacrificed to the Selfness" (Moacanin, 2004, p. 75).

The practicing can choose one or several yidams for visualization. The great masters of the past directly assigned yidams fitting spiritual mood of their pupils based on their karmic predisposition: "Your Yidam is such."

Let us study several texts - practices of yidam visualization:

"...Visualize Amitahba, Buddha of the Boundless Light, sitting over the crown of your head, and imagine around yourself all living creatures, in particular, to the right of you - your father, and to the left - your mother. Then imagine your friends, family, enemies, and all other living creatures of six worlds around yourself, and over the head of each of them - Buddha. During iteration of the six-syllable mantra, a nectar, like milk flows from the heart of Buddha Amitahba, gradually penetrating through the crown of the head and filling your body. Then all extinguishments and misdeeds begin to leave your body. The same as the content of a vessel leaks through the opening in its bottom, all your misdeeds and extinguishments in the form of a liquid soot leak through your bottom openings and feet. The earth opens wide beneath you, and streams of soot flow downwards, where Yama, the Lord of Death, swallows it up. Imagine that you satisfied and sated it, and result paid your Karmic debts by means of this practice. Then, imagine that you have cleared from all improper deeds and extinguishments, disturbing emotions, dual perception and habitual inclinations. Your body becomes irreproachable, dazzling, and glaring as a crystal ball. Telling prayers and mantras again and again, you imagine how Buddha Amitabha disappears in the light. His light-bearing forms are similar to a rainbow already, but at this moment he dissolves and interflows with you, so you become inseparable from Amitabha. His enlightened Body interflows 
with your body, his speech - with your own speech, his mind - with your mind, fully and inseparably, as water interflows with water. At this point you should be in the original clean Great perfection, self-existing awakening. Then you imagine that you received all four dedications. It means that you have reached all enlightened qualities, possessed by Buddha Amitabha, so his loving sympathy and activities become your own. With the great delight and pleasure you are in peace" (Choki Nima Rinpoche, 2002, p. 115).

To understand Buddhist theology, it is important to mark out the nature of creatures, which are yidams for the practicing. If in Christianity the appearance of the image of the Mother of God or saint Nicholas before believers, it is perceived as the extraordinary event, where the reality of these sacral figures should not be doubted, and the fact of appearance is considered as the grace, sent down, but for practicing Buddhist the meditation on Yidam is the daily practice, and the question about the form of existence of the yidam has different answers for the buddhists, being on different levels of the Study comprehension (and, correspondingly, on different levels of the spiritual development). For the mass of believers these deities are really existing, requiring gifts and worship.

We were in Ceylon in the temple of the "Buddha's Tooth" in the ancient capital Kale, one of the main religious centers of Hinayana (Small chariot) of the South-Eastern Asia. Offering of fruits and milk to the "tooth of Buddha" placed inside the golden statue of Buddha was accompanied by a magnificent ceremony and roar of trumpets, which could be completely interpreted by a representative of Abraham religions (Christianity, Judaism, and Islam) as the pagan ritual of idolatry. Possibly, in the mass conscience of believers it is partially true, and Buddha Shakyamuni from a quite certain historical personality of the learning founder turned into their conscience into a supernatural creature. In the hagiography of Buddha there is a biography of quite an earthly man Siddhartha Gautama, and in later sources - his mythological image. According to these sources, "Bodhisattva, who was touched by hardships of people, gods and spirits, took the image of a white elephant, coming out of Tushita sky (the place, where gods live), decides to insert the embryo of the future Buddha in the right side of the chaste princess Maya. He stays there exactly nine months. Maya gives birth to Buddha while standing, embracing a tree with her right hand. In seven 
days she dies. Her sister Mahapradzhapati Gautami nurses Buddha. The clairvoyant Brahman Asita foretells the great future for the infant. At the moment of birth, in the Lumbini park flowers are falling down from the sky, the music of the spheres sounds, a canopy flies in the air, the worlds are waving, the event is accompanied by the unusual shining and miracles, signifying his greatness. (Buddha began speaking right after the birth.) He said he would put an end to reincarnation, old age, diseases, and death" (Luz \& Michaels, 2005, p. 24). The image of guru Padmasambhava the founder of Tibet Buddhism is mythologized. According to the legend, he was born not from the body of a woman, but was found in a lotus flower. Having received the siddhi of immortality, he stays in the same body and becomes visible in the right place at the right time. Showing the world many miracles, he (same as the prophet Mohammed), flew on a winged horse. ${ }^{12}$

At the same time, mythology or de-mythology of the image of the Teaching founder are not as important for the practicing Buddhist, as the Teaching itself - Dharma, and the colorful biography is called on to rather emphasize the significance of this event for the one who is writing and the ones who are readers. The canonical structure of sutra, as a rule, includes the words: "I heard so" or "I was told so," called to underline the authenticity of the text, but implicitly making hints about the subjectivity of the interpretation, about the partiality of the heard. ${ }^{13}$ O.O. Rosenberg (1991) notes that in the Buddhist mentality the objects do not exist separately from the observer and, for example, for a person, watching an event, it becomes a part of his internal world. For example, a human does not exist separately from the sun, but "there is a uni-

12 Nevertheless, mythological components rather poeticize the mentality and can quite coexist for the enlightened Buddhist with the deep reflexion of the existence. Thus, the great Buddhist philosopher of the 5th century Vasubandhu in his "The Cist of Admiharma" considered the hell in accordance with the learning of Kashmirian vaibhashiks as a quite real place in the nether world, and in his work Vimshatica vidzhnaptimatra siddhi (it means - Twenty verses about the conscience), written from the position of a yogochara, determines the hell as only the mental illusion, objectification of conscience of a "sinner" (see Torchinov, 2005, p. 54).

13 Buddha preached Dharma allegorically, adapting himself to the level of listeners' development, considering their mistakes and prejudices. Hence, the "Buddhist hermeneutics" singles out two types of sutras: sutras of the "final meaning" (nitartha) and sutras, requiring interpretation (nejartha). 
fied field of experience - a human watching the sun." The reality for the Buddhist is not the world, where we live, but the world, which we experience "The world as a 'residency' clearly correlates with the level of conscience development of different living beings, and one and the same world in oneself turns out to be completely different psychocosmoses for different living beings. As later one Mahayana thinker said, that what the river Ganges for a human was would be the flow of pus and sewage for a hungry spirit, and the flow of ambrosia for a deity. And only Buddhists of the school yogochara did not consider it possible to affirm that some objective, 'correct' Ganges underlied these subjective 'Gangeses'” (Torchinov, 2005, p. 53).

Enjoying the beautiful quotation of E.A. Torchinov, the authors, nevertheless, draw attention to the fact that in Torchinov's statement "one and the same world in oneself" implicitly means the presence of some invariant ("one and the same") Kant's "thing in itself" that, evidently, is alien for the school yogochara. According to their view, there is only consciousness (Chatterjee, 2004) and thus, there is no not only objectively "correct Ganges," but there is no "one and the same 'world in itself," for different "Gangeses."

The thought about the involvement of an observer, his partial position is utterly close to the modern cognitive linguistics. For example, A. Wierzbicka underlines that beyond so-called subjectless opinions, such as "it is getting dark," there is a position of an observer, who in the right place at the right time is watching this process. The mentality is subjective, from this, the pluralism is possible in the position of an observer and his partiality.

In monotheistic religions the God opens in his personal hypostasis, being simultaneously the Absolute system of countdown, the bearer of the absolute knowledge. Jesus Christ announces: "I am the way and the truth." And if F.M. Dostoyevsky puts a phrase in the mouth of his character, which could quite characterize the righteous Christian himself: "If on one scale there is the truth, and on the other - Christ, I would prefer to be with Christ rather than with the truth," but Buddha himself called on his pupils to trust, first of all, their own experience, their practice - "to be lights for themselves."

As J.L. Borges writes, "Other religions (unlike the Buddhism) depend to a greater extent on our ability to believe that one of the Holy Trinity condescended to the earth in order to be a human and to be crucified in 
Judea. If we are Moslems, we should believe that there is no god, except Allah, and Mohammed his prophet. We can be righteous Buddhists and decline that Buddha existed. Or, better to say, we can think, that our faith in his historical existence is not important, the faith in the Study is important." And later, "...to believe in the historical existence of Buddha or to be interested in him would be something similar to mixing the study of mathematics with the biography of Pythagor or Newton. One of the meditation topics of monks from China and Japan - is doubt of Buddha existence. This is one of doubts, which they should overcome in order to comprehend the truth" (Borges, 1995, p. 22).

In the research dedicated to the hermeneutics of the Buddhism S.Yu. Lepekhov, A.M. Donets, and S.P. Nesterkin (2006) believe that it is possible to speak about the religious and non-religious Buddhism. O.O. Rosenberg (1991) has the same thoughts.

Here is a characteristic of the enlightened or arhat: "A person, who does not believe and knows the unformed, broke the attachments, put an end to the event, refused the wish, - he is the noblest man" (Dhammapada, 1991, p. 19).

Buddha called such people "unbelievers" in a sense that they had neither faith, nor beliefs, they have the knowledge because of the heartfelt meditation of enlightenment. The one who believes, does not know yet. Plato, who lived approximately in times of Buddha Shakyamuni, expressed this thought so: "a wise man does not need faith, he has the intellect."

We asked Buddhist lamas of Buryatia (both Buryats and natives of Tibet), as a rule, highly educated people, the following question: "In the modern physics there are often used such notions as: 'demon of Laplas,' 'demon of Maxvell', where the term demon is personified by some physical principles, regularities, which could be realized by a hypothetical 'someone' or 'something.' Moreover, certainly, physicists do not suppose the real existence of these demons, the same as a modern person, speaking about the poetic muse, elves, and gnomes, does not suppose their real existence and unlike search for the Loch Ness monster or a yeti, does not organizes expeditions to discover them. So, are Manjusri, the White or the Green Tara the real characters or not?" We received different answers, but the most full answer we found in the book by Choki Nima Rinpoche (2002): "Finally, - writes Rinpoche, - colorfully decorated deities with many arms and symbols do not exist in reality either as real or 
material. Taking this practices, we can remove our usual inclination to perceive things as dense, for example, our belief in material existence of the physical body, the sound of our own voice so on other. If we visualize the body of yidam, repeating the mantra as a speech of yidam and practice Samadhi mind (the state of the meditative concentration) of yidam, then these effective techniques provide skilled means to clear these habitual stereotypes, which contribute to the material perception of the reality." Rinpoche extends the principle of illusiveness of being to the images of deity as well. "While practicing deity, we very often and easily reach siddhi (abilities) of his body, speech, and mind. While a deity - Yidam personifies the full enlightenment, qualities of renunciation and realization, then with the practice of such deities as Manzhushri or Avalokiteśvara, the same qualities, similar to the image, cast from a mould, would appear in us very fast. Visualization of a deity's image in the form of our own body eliminates the implication to the perception of the dense reality.

"...However in the absolute sense there is in fact nothing as a body of yidam or his speech. There is no such material substance as yidam. The real worlds of Buddhas also do not possess the real existence" (Choki Nima Rinpoche, 2002, p. 36).

With such interpretation the notion yidam, in our opinion, has something in common with the notion of introjection in psychoanalysis. The image of a father or significant another, according to S. Freud, appears as a model (a peculiar yidam) in the process of socialization of a child, the starting mechanism of whom, according to Freud, is the Oedipus complex. Identification of a child with a father is on an unconscious level, and a child, unlike the purposeful practice of a Buddhist, meditating on "another significant" (yidam) and identifying himself with him does not consciously control the process.

Nevertheless, the effect of identification with another significant or even the fact itself of the presence of another significant in one spatial locus changes essentially not only the behaviour of a child (see of E.V. Subbotsky's researches (1983) on the moral development of a child), but according to A.U. Kharash (1980) even strengthens his creative potential, stimulating creative motions while solution creative tasks. The evidence of the existence of "one being in another" (a term by A.V. Petrovsky and V.A. Petrovsky) is realized in ingenious experiments carried out by I.P. Gurenkova, V.A. Gryazeva, A.N. Smirnova, 
E.Y. Uvarin under the guidance of V.A. Petrovsky (see Petrovsky, 1996; Gryazeva \& Petrovsky, 1993).

In this experiments the presence of the portraits of a "beloved" or "not loved" teacher caused either the expansion or narrowing of the creative search zone of the task suggested by the experimenter. In modern psychotherapeutic practice the systematic work with images has not become a widely spread practice yet, and only talented individuals resort to it, using it both for practicing psychological correction, and the development of the creative potential of a person. So, V.L. Raikov's experiments (1992) with the infusion of a personality of a great artist to the subject became classical ones. The subject didn't only begin to draw better (according to experts' estimations), but also revealed in their creative work the signs of the writing style of a suggested personality of a painter. Raikov exhibited full art galleries of the creative work of patients with the suggested personality of great artists.

However, one can suggest that the measure of patients' identification with the personality suggested in the hypnosis is not quite full. We witnessed a funny hypnotic session held by V.M. Shklovsky in the seventies of the last century within the framework of the Psychological school of young scientists. The diffident, repressed patient was suggested a personality of A.S. Pushkin and he, "having entered his role" and walking on the stage as if it were a pavement of Tsarskoe selo, recited poems of the great poet with inspiration (whom he was at that instant), and it obviously gave him great pleasure. Shklovsky introduced a third person in the situation (the late P. Shikhirev), introducing him as a lycée friend of Alexander Sergeevich - Kuehelbeker (Kuehlei, as he was called by the close friends from the lycée brotherhood), and offered to drink to friendship. Our patient, having accepted the offer with delight and "having drunk the champagne," unexpectedly for the hypnotizer himself, in keeping with the best traditions of hussar feast, stroke the table-glass against the floor, showering pieces of glass at the audience watching this action. At the high point of the emotional excitation Shklovsky exclaimed: "And now to 'Yar,' to the Gypsy, to girls!" and after that the emotional excitation of the patient suddenly changed to anxiety. He obviously changed: "Let us not go to the girls. There can be conflicts, duels." That is, the deep protective motivation, protection mechanisms of a person remained the same peculiar to our anxious patient and limited his fantasy activity. The hypnotic suggestion of "an- 
other person," evidently, does not transform the personality of another completely, but accumulates it, functioning within those limits, which are allowed by the moral values, ethical norms of the personality, exposed to suggestion.

The given examples of psychotherapeutic (or something like that) practice of the introject or the "significant another" to the personality of a patient, are close, in our opinion, to the practice of meditation on yidam, but with the significant difference in the chain of interpretation, because the principle of "anatta" in the Buddhism declines the reality of a personality ("I" or ego), the same as another reality. The Buddhist concept of emptiness ("shunjatta") affirms the illusiveness of the world represented in sansara as the illusiveness of the observer's personality. Unlike the academic (western) American and European psychology (to where the Russian one belongs too), where a personality is the top of the mentality, and "I," under the vivid expression of O. Külpe (1914), the sovereign (the host) of psychic functions, the Buddhist ideology supposes them to be the illusion of the shaded consciousness. Buddhism denies what the Brahmanism or Jainism called "jiva" (soul) or "pudgala" (personality). "Everything that we consider to be 'ours' or 'us,' for example, 'my house,' 'my family,' 'my body,' 'my thoughts,' 'my views' all these are not ours, because in reality there is no owner" (Kvantipallo, 2005, p. 64). In the Vedic Brahmanism, where and in opposition to which the Buddhism appeared, there is a notion "Atman" - in a way "holy sparkle," which exists in any living being, which then returns, joins the ocean of the cosmic Absolute (Brahman). But in Buddhism the principle of "anatman" denies the existence of "I," underlining the illusiveness of this experience.

Reasoning of Buddhists, in particular, schools Yogachara and Majahjamiki prosantics, in our opinion, are close to modern constructivism (Kelly, Gergen, Petrenko, Harre). So, R. Harre, callings on psychologists to switch their attention from the search of "I" as some essence, which should be revealed and described, to the construction of "I."

In the constructivist approach in the manner of G. Kelly man's consciousness is considered by analogy with the work of a scientist, who constructs the models of the world, himself and other people. "Personality" or "I" are considered as cognitive constructs, "I - concepts," built by our consciousness in order to bind the individual experience, and integrating those events, the witness of which was the consciousness. 
Buddhists express similar ideas of "non-substantiality," illusiveness of "I" more figuratively. "This is as if a mountain path were be obstructed with stone blocks and crumbled earth; and in order to climb the top, someone clears and makes even the path, until he finally manages to climb to the top and reach the horizon. These factors of enlightenment can be compared with the cleaning and leveling of such a path. The only difference in this comparison is that when the full view is open, it turns out that there is nobody on the top!" (Bhikku Kvantipallo, 2005, p. 79).

The idea of illusiveness of "I" has a great psychotherapeutic effect. If in psychoanalysis the effect of displaced into the unconscious traumatic experience is taken away by means of its perception and rethinking. "In place of It there should be Ego" (Freud supposed). Thus, through the perception and thereby through the generalization (there is a human culture beyond the consciousness), the effect of the solitary originality of psychological trauma will be withdrawn. ("This can happen with anybody"). "Don't count out a prison cell, a begging bowl may come as well" says a Russian proverb. The solitary affect dissolves in the general social.

Buddhism in the concept "anatman" (Sanskrit) or "anatta" (Pale) goes further than psychoanalysis, withdrawing the effect of suffering just in the absence of the addressee. "I" as the temporary passing combination of dharmas (elements of the consciousness) simply does not bear the burden of the past behind its back. The perception of the illusiveness of "I" withdraws the problem of the personal suffering, substituting it with the suffering to all creatures: people, animals, deities, spirits, etc. Instead of I (Ego) the Buddhism places the Unified Existing (the unity of all living beings).

Let us study another example of yidam: "On a clear and clean moon disc you place a syllable source. This syllable irradiates beams of brightblue color, which distribute vast and live sympathy, radiating beyond the sky and space. It satisfies the needs and fulfills wishes of sensitive creatures, bringing with itself the hot and hearty atmosphere that allows to illuminate the confusion. Then, based on this source syllable you create Mahavajrochan Buddha of the white color with features of an aristocrat - a child of eight, innocent appearance, clean, powerful, royal, $\mathrm{He}$ wears the costume of an Indian medieval tsar. He wears the sparkling gold crown with the encrustation of magic valuables to make wishes. A 
part of his long hair streams down his shoulders and back; another part forms on the top of his head a flock, decorated with sparkling blue diamond. He sits in a pose of lotus on a moon disc, his palms are folded in the mudra of meditation and hold vajra, inserted in a clean white crystal" (Moacanin, 2004, p. 77).

This practice, as we suppose, is connected with the individual cleaning from negative emotions, awakening of a child in itself, the brightness and cleanness of feelings. In the modern hypnotherapeutic practices (for example, in the work by Milton Erickson, V. Kucherenko) a regress into the past is used, when a patient, being in trance, actualizes emotionally saturated pictures of the past from the depth of his memory, the energy of which changes colors of the present day: "I am a little girl with big bows twisted in the plaits, with a large bunch of peony, I go to the first form in the school. My mother - very young - leads me. I look down and see a knee beat after I fell down from a bike. I have the same leather sandals and white socks on. I take my mother's hand and look into the blue sky. I am uneasy and joyful."

Another example of the report of a patient of 60, who took sessions by us with regard to a hard somatic disease: She is one and a half. She is in her mother's arms. They are on a high shore and look at the sea in front of them. She sees the sea for the first time. She feels the smell of seaweed. The father is next to us. The father and the mother are young. She wears a light dress and shoes. The question of a hypnotizer: "How are the shoes fastened?" she replies: "with a button." This method of the age regression enables to actualize the image of "I" and the scheme of the body at that time, when a man was young and healthy. Until then, the patient could not control the movement of her arm; after the course of sessions she began to control both hands equally well.

Another example of yidam visualization, connected with the mahayan practice "Tong-len" ("to give and to take") is given by Choki Nima Rinpoche: "We imagine ourselves in the image of the Great Sympathetic, white awakened Avalokiteśvara, and visualize that the sun's beams, which represent our merits, our knowledge, sympathy, virtuous karma, glory, success, etc. other, come from our body in all directions. They stream outside and disperse like light beams, falling down like snow flakes, showering living beings and dissolving in them. Thus, we distribute all our positive energy between all other creatures. Then we imagine that all their sufferings, bad karma, etc. are absorbed in us. Finally, we imagine 
that we improved the accumulated merits, and that our body in the image of Avalokiteśvara became even more bright, sparkling and clear, than it was before" (Choki Nima Rinpoche, 2002, p. 50).

If in the Buddhists practices of visualization, as a rule, the image of yidam is used, taken from the sacral (mythological) pantheon, the bearer of one or another essential mental states, then the object of contemplation can become the ordinary domestic object.

There is a story, how a buffalo shepherd became a pupil of Nagarjuna (one of the great Buddhist teachers, who lived in India, presumably, in the $2 \mathrm{~d}$ century). The shepherd experienced difficulties during meditation on yidam, because during his whole life he tended a herd of buffalos and got accustomed to see only their faces, images of which penetrated his head, while he was concentrating his attention. Then, Nagarjuna recommended his unlucky pupil to try imagining himself a mighty buffalo with protruding horns during meditation. The shepherd practiced that for a long time, and once Nagarjuna received a message from him, where he apologized for not visiting the teacher for a long time, because he could not come out of his cave because of too long horns. They appeared to be wider than the exit from the cave. Nagarjuna sent a reply, where he said: "This is very good. You reached some stability in shamatha (the practice of meditative calming of mind), and now you should visualize the horns to disappear." Having practiced such visualization, the shepherd could leave the cave in some time. "This story, - writes Choki Nima Rinpoche, - is not merely a joke. Due to the stability of mind, acquired at this state, later it was easier for a pupil to receive instructions. It was a skillful method, applied by Nagarjuna, because that person could not concentrate on nothing else, but the head of a buffalo" (Choki Nima Rinpoche, 2002, p. 63).

This almost comical story has a direct analogue in our practice of hypnotherapy. For the purpose of energetic boost, patients were suggested an image of a huge, mighty tiger, with which they identified themselves, i.e. imagined themselves to be this tiger (if using the Buddhist (Tantric) terminology, this tiger was the yidam for patients). Patients felt themselves a strong mighty animal, walking softly and elastically on its paws. Patients felt that they were able to jump ten-fifteen meters high. While practicing this one of the authors of this article experienced an unusual feeling of his face stretching to the width of the animal face and 
the increase of the distance between eyes. A strong, resilient body was full with life and energy. Later patients learned to enter this image of a tiger, when it was required by the painful physical state or the intensive domestic situation. Patients used this method in life with great success, but once one of the patients confessed: "I enter the image of a tiger, when I feel uncertainl in my firm. Everything would be fine, but the tail would strike the floor all the time." Another patient, after he was suggested the image of a mighty giant, driving to his work place in the mornings, and entering the tunnel, bent down instinctively.

If in the Buddhist practice of visualization on yidam his role is played by some enlightened male or female deity, then in the psychotechnic of psychotherapy the images of visualization are not given beforehand, but spontaneously arise during concentration of attention and interruption of a verbal consciousness. A patient can feel himself a small crying child, then he sees himself as a menacing medieval knight, galloping with a spear atilt, with curling red plume on the top of the fighting helmet. Then he feels himself a butterfly, flapping with its wings, who is thrown to one or another side by cross-wind; and suddenly - a bird pecking a butterfly, and now sky-rocketing on resilient wings to the blue of the sky, or even a drop of dew on a green leaf, sparkling in the sun. The choice of one or another image and the logic of their transfer (same as the dream dynamics), evidently, is dictated by the internal dynamics of emotional states of the patient, the grammar and syntax of which is still to be understood and reconstructed. In any case, the logic of unconscious, that becomes apparent in the sequence of the arising images, and in their content is conditioned by the tasks of $t$ "work experiencing" ("the work of grief" in terms of Vasilyuk, 1984), and is connected with the self treatment and harmonization of our mentality (or soul).

Along with the enlightened images of Bodhisattva in the role of yidam can also be angry defenders of the study, inducing fear and trembling on the practicing. Let us study the description of one of these deities: "Mahavajrabhairava should have a body of intensively blue color, nine faces, thirty four arms and sixteen feet. Legs from the left side should be in front, from the right - in the back. He is able to swallow three worlds, $\mathrm{He}$ giggles and makes strong shouts. His tongue is curved inside, He grinds his teeth and frowns. Tongues of flames shoot out of his eyes and brows, like space fire in the moment of destruction of the Universe. His yellow hair is endless. He threats deities of material and immaterial spheres. 
He frightens even the horrible deities. He exclaims the word 'suffering' by the voice like a rumble. He eats human flesh, marrow and fat, and drinks blood. His head is crowned with a wreath of five horrible sculls, and he wears the necklace of fifteen freshly cut heads. His sacrificial cord is in the form of a black snake. His earrings and decorations are made of human bones. He has an enormous belly, he is naked, and his penis is erected" (Moacanin, 2004, p. 76).

A reader can be perplexed by the necessity of visualization, and through it the identification of the practicing with such a horrible image. What siddhi (supernatural qualities) can we obtain, identifying ourselves with him? And here, again, the parallel with the psychotherapeutic practices is evident. In psychotherapy of children, who suffer fears (they are afraid of an old witch, vampires or other monsters) they use the method, when children draw terrible characters or they illustrate them themselves, playing their roles. Howling wildly, a child is running around the room, illustrating a monster: "We are horrible, horrible witches." When playing a negative, but mighty character, he himself becomes almighty, threatening others. And at the same time, the possibility for self-irony appears. In this way he does not identify himself with the malicious character in full, illustrating him he grotesquely exaggerates his characteristics and thus, sort of moves away from them. Like an actor of Brecht theater of masks, he does not identify himself with the character completely (the same as in the method of assimilation in Stanislavsky's directing), but sort of commenting them.

The interesting psychotherapeutic and, let us say, the director's discovery, "the method of emotional inversion," belongs to V.V. Kucherenko. An unconfident, worried child, who is undergoing psychotherapy, is suggested an image of a night forest. Here he is going along a forest path, the brushwood crackling under the feet, an eagle owl hooting somewhere, shouts of night birds can be heard, the roar of animals, and trees acquire odd shapes of threatening giants. Suddenly, two huge luminous eyes look at him without blinking, point-blank from the nearest bush. The horror grips the child. The body is constrained, feet are stuck to the earth. It is not possible to run. Horror! Horror! It is not possible to bear this horror.

And suddenly, from behind bushes, where two phosphorescent eyes were looking at the child, a small black kitten is crawling out, with enormously wide opened pupils of horror. It has lost its mother, it is trem- 
bling with fear. Its huge eyes are look at the child beggarly. It needs help. There is a transformation of the situation and catharsis:

"This is who really needs help and protection. And you are so big and strong in comparison with the kitten, and you can help him." And now the child feels himself a giant and a defender of a weak. He is big and kind, and is not afraid of anyone.

Another function of meditation to terrible dangerous situations, for example, "meditation on death," "meditation on corpses" (see Nyanaponika, 1994) is connected with cultivating of non-attachment to the body (chod practice - cutting off fear), with the necessity of perceiving of illusiveness of "Self" (principle of an atman), and in psychotherapeutic practices - with the activation of the instinct of self-preservation and activation of the immune system work. The experience of the weight in the body is being suggested, impossibility to move, as if you were sucked in the fat, stinking bog. The marsh slush is squeezing the body harder and harder. Bubbles of marsh gas slide up the body. Marsh leeches are biting into the skin. Remnants of decaying plants and carrion remnants of animals penetrate into the mouth. Choking, a man feels cramps, convulsions. After experiencing the death agony, a feeling of the decaying corpse appears. Death spots appear on the body. The meat decays, streaming down bones. The whole body sort of dissolves in the marsh.

With the dissolving, disappearance of the body (for Buddhists this experience is equal to the loss of ego), a person is released from the threat of death. "Self," losing its physical coat, appears inside a vaster and richer image (space): Elements of the body scheme ("Self" cover) are movements of air streams, streams of the sun light, water and forest expanses. The life in all its display.

There is only the forest edge, on the marsh edge, covered with the bright greenery. The sun is bright. Snow-white clouds flow along the blue sky. Singing of birds is heard. Everything is filled with movement of sounds, colors. Everything is full with the movement of life.

By this example, one can feel that the work on visualization in altered states of consciousness is connected with the change of categorization, with the removal of the subject-object opposition of "Self" and the world, or "removal of duality" as it is called in the language of Buddhism. The borders of self-identification are changed. In the state of meditation the physical body sort of dissolves in very different manifestations of 
"God's world" and consciousness is in resonance to the whole world. In the altered states of consciousness the categorization of oneself, other creatures, changes. Experiences of deep meditation are hard to express in the natural language. Verbal, expressed in the language, consciousness is fundamentally directed to objects of the outer world, i.e. intentionally and, so to speak, serves the social being of the human. Even being directed inside oneself, it remains a mediated language, social and culturalhistorical, i.e. partial. A person looks at himself with eyes of his epoch, his culture, his religion. Consciousness is culturally-historical (Vygotsky \& Luria, 1930/1993; Leontiev, 1981; Cole, 1997; Asmolov, 1996; Shkuratov, 1997) and by the virtue of this is inevitably partial, because it is called on to perceive the world based on the needs and requirements of a person, on his motives and values; consequently, from the point of view of Buddhist philosophy it is "saddened," including cliché (emotions and affects), binding a person to the world of samsara.

Verbal perception is discrete and discursive, and semeiotic. It categorizes the world based on the logic of the language (see Sapir-Whorf theory of linguistic relativity), inherently discrete and follows the logic of the same language expressed in syntax and grammar. "Any attempt, - writes Torchinov, stating and interpreting the views of Nagarjuna in Sutra of the Heart Pradzhnja-Paramity, - to create metaphysical system adequate to reality is doomed to failure: thinking that we describe the essence, we describe only our ideas about the essence, created by our differentiating thought, making subject-object dichotomy as the condition of the empirical cognition. In the beginning we hang labels to reality, and then we start to study them, taking them as the reality or, in other words, we take the finger pointing to the moon for the moon" (Torchinov, 2005, p. 126).

In the theory of personal constructs G. Kelly gives the explanation of the language as the instrument for constructing mediated knowledge in the form of the world models, other people and oneself. The language is the "home of being" (Heidegger) enabling a person to make the space of existence habitable and to limit its borders.

However, as religious practices, meditation and psychotherapy show, apart from the channel of world perception, there is also a channel mediated by language (or channels) of the direct, non-mediated knowledge. Non-mediated knowledge has two forms or aspects, which can be conditionally marked as the horizontal and vertical. The horizontal channel - 
intuition (in terms of Henry Bergson, 1998; Lossky, 1992) or empathy, enabling one living being to share, to sympathize with another, to feel the pain and sufferings of another creature, to feel his emotional state. ${ }^{14}$ As the authors of the collection Psychotherapy and Spiritual Practices write: "The pain and anxiety of a client - is a sort of a call to a therapist to leave his attachment to the position of an expert and instead to penetrate in to the world of the client's psyche mentality, and to share with him his misfortunes. Dealing with the fear of a client, a psychotherapist finds out that he gets the possibility for further handling his own fear. Helping somebody to investigate the sense of emptiness and loneliness, lying in the depth of one's most intimate relations, the therapist simultaneously receives the chance to notice this part of his one psyche mentality and to establish relations with it too. In reality, there is only one consciousness. Though for some people it can sound as some strange mysticism, nevertheless: at the moment of a real contact between a client and a therapist perception of a therapist and a client are two ends of one continuum" (J. Needleman, R. Skinner, J. Wellwood, E. Fromm, R.D. Sasaki, 1998, p. 8).

The work of the empathy channel is shown in the phenomena of love, altruism, play-acting; due to it, we empathize with characters of a theater and cinema, becoming these characters for some time. The work of this channel can have not only a positive, from the point of view of human moral, but also a negative sign. So, aged, suffering impotence Roman patrician experienced sexual emotions, watching sexual orgies of slaves, identifying themselves with them. Or serial maniacs and sadists, like Chikatilo, urging their own impotence of senses through empathy of pain, caused to the victim.

In case of fiction and poetry, with their fictitious characters ("golden cloud spent the night on the chest of a giant cliff"), it is more difficult to explain in the spirit of $\mathrm{H}$. Bergson, empathy as the imaginative insight of

14 A. Bergson gives an example of intuition that as the wasp-ichneumon gives a paralyzing sting into ganglions of a caterpillar in order to use it as the food for its own maggot. The wasp accurately finds ganglions of the caterpillar, but not as a result of "trial and error" (as it follows from the theory of study in behaviorism), and due to the intuition feeling these ganglions in herself, modelling by means of its own mind other's fleshliness. The mechanism of intuition, according to Bergson, is possible by virtue of the fact that live organisms have common evolutionary roots, allowing to identify a living one with relation to another living. 
the living beings towards living beings. Though it is possible to suggest that there is quite a real author, beyond the fictitious characters, then we empathize with emotional movements of his soul, or we admit, the existence of thought-forms as an object of empathy, created by the creativity of a writer, in the form of introjects. Let us recall from Pushkin: "I'll shed tears over fiction," images of the "Steady Tin Soldier" or "Darning Needle" by H.C. Andersen.

Empathy or intuition means some activity of the one perceiving "updating" in terms of NLP (see Grinder \& Bandler, 1995). We, (the audience) hold our breath, strain ourselves at the moment of danger for a screen character. It is desirable to take a position, to breathe in the same rhythm as the person, to whose the consciousness of which a hypnotizer (a suggestor) is tuned. During hypnosis it is difficult to feel oneself a bird, sitting with hands folded. Only spreading them ("open out wings"), one can feel the cross wind, feel the pressure of the wind and gliding on elastic wings, leaning against air flows.

The vertical channel of the non-mediated, deprived of categorization perception is connected with full cessation of any mental activity. The concentration of attention on a nonobject object (like flatness or space of certain colour) leads to the stop of the flow of thoughts, images. Analyzing the concept of "enlightenment" in Mahayana-Shraddhotpad-shastra N.V. Abaev (1991) writes that according to this shastra, the real ("unshadowed") consciousness possesses the immovable nature, but clichés (emotions and wishes) cause the movement of thoughts.

"This is like the water in the ocean, the waves of which rise under the pressure of the wind. Similar to that, consciousness of a person, clean by nature, starts moving (i.e. becomes excited) under the pressure of the wind of ignorance. The perception possesses the immovable nature, and if ignorance disappears, then the flow of false activity ceases too, but the nature of wisdom remains unchanged and does not disappear" (Aśvaghosa, 1989, p. 251). In the above quotation of shastra there is an idea of passivity of the true "unshadowed" consciousness, diametrically contrary to the ideas about consciousness in the theory of activity by A.N. Leontiev (1981), S.L. Rubinstein (1935). In A.L. Yarbus's (1965) famous experiments, where with the help of a sucker the object of observance is established directly on the eyeball of an observer, thus depriving him of the possibility to scan the object, i.e. to perform the 
movement activity of the eye in the field of perception. The object, after some quite insignificant time disappeared from observer's field of vision, and became invisible for him. These experiments illustrate the idea that the process of perception and consciousness need active actions of the observer himself. V.P. Zinchenko and N.Yu. Vergiles, reproducing these research, showed that it is possible to support the object perception not only by the external activity of the eye movement, but also by the internal actions of attention switching. These movements of attention along the field of stabilized image were called by them "vicarial perceptive actions." The possibility of vicarial perceptive actions, at least, the questions of complete denial of any activity of the subject in the condition of "unshadowed," non-mediated, connected with the "vertical" meditation of consciousness, and needs its own experimental solution. Electrophysiological research of encephalograms of people in deep meditation shows the non-reducibility of their biorhythms either to sleep or to wakefulness, and enable to make hypothesis about neurophysiology of special altered states of consciousness.

But let us return to the meditation as the vertical channel of the direct non-mediated perception. In different traditions it appears as "insight," "yogi intuition," "direct vision," "prophetical vision." Meditative knowledge is integral and not discrete. It does not contain any constructs. "It does not have the features 'good' and 'bad,' 'big' and 'small', 'beautiful' and 'ugly', this is where its non-duality lies. Its essence is absolutely clear." And then... "In meditative practice there is a process of transfer from sampradzhnjatasamdhi to asampradzhnjata, where the contemplator loses in the object of thought its form and differences. Instead of the observed object, there appears uncertainty, abyss, something contrary to all phenomenal. Here at this moment, losing the phenomenal nature of the object, the individual discloses in himself the noumenal reality of the world. Through the coincidence of the felicity and shunia (emptiness) he discovers wisdom (dzhniana)" (Dandaron, 1995, p. 12).

And after we determined meditation as the direct channel of perception, then the question remains open: perception of what? Is it possible to discover any positive information about the world, about oneself, about the past and the present, and maybe about the future?

(The ideas about the timeless character of meditative states allows for such possibility: "Mahamudra - is not an event in time, it is more likely is 
the time, not limited by the precious 'now', but including the past and the future, about which we usually think as about non-existing" (Guenther, 1963, as cited in Dandaron, 1995, p. 18).

We do not presume to confirm or decline the possibility of "looking" in the meditative state into the past or the future, at least, within this article. What we affirm for certain! Meditation, through the concentration of attention, through multiple reiteration of mantra stops the "flow of consciousness," interrupting the process of verbal categorization. Categorization (or mediated by meanings according to A.N. Leontiev) of everything that L.S. Vygotsky called the highest mental functions (perception, memory, attention, thinking) enables a human to use the experience of mankind, the experience of ancestors, crystallized in meanings. But the experience while enriching also limits simultaneously. "The limits of my language determine the borders of my world," wrote L. Wittgenstein (2003, p. 5). Meditation removes (temporarily, for a person, who did not reach the level of perception the bothisattva) all possible forms of categorization, including the categorization of the own "Self." Or rather, based on the principle of "anatman" (illusiveness of "personality"), that reflexing consciousness, which, based on the events of the past, the opinion of others, the self-appraisal, and so on, categorizes itself, creating "Self" the image. De-categorization of "Self" reminds of E. Titchener's "removal of the stimulus mistake," i.e. that specific setting of consciousness on removal of object images, when instead of known items (for example, a book lying on the table) a psychologist, within the framework of the analytical introspection, describes contours and change of brightness, color spots, corresponding to "phenomenal fabric" of what we call "a book" during categorization. However, unlike to the setting upon removal of the objective world during meditation, consciousness is directed into itself. The altered states of consciousness lead to the changes of the categorization forms of the world, oneself, others (see Petrenko, Kucherenko, \& Välbe, 2006). The process of de-categorization of "Self" removes stereotypes of the accustomed forms of perception of the person, the significance of "Self." And here this process, is likely, to be coherent with the most important human problem - the problem of spirituality. Under spirituality we mean the finding of the meaning of human actions and of the life itself. Something (an act, an individual's life, existence of civilization, existence of mankind) has got some meaning in the context beyond 
the framework of the determined, in the context of something bigger, where this something is included. Coming up the "spiritual vertical line" (see Vasilyuk, Zinchenko, Znakov, Siderskiy, Shadrikov, Shestun ${ }^{15}$ ) a person realizes both the transiency of his own being and his significance as a link of the generation, the bearer of the national and general human culture and, finally, the bearer of a particle, a sparkle of the World Spirit (or the Integral consciousness). In our opinion the phenomenon Spirituality, which appeared in within the framework of religious consciousness, where the highest criterion of the eternity is God is not only the phenomenon of religious consciousness. Expansion of the borders of identity, expands the context of existence and fills a human existence with meaning making it spiritual. The process of meditation changes the forms of categorization of the world and oneself, expanding the borders of identity, removing any forms of categorization in general. Within the limit, de-categorization leads to the perception of emptiness (sunyata), and the state of altered (i.e., deprived of categorization) consciousness to nirvana. Moreover, nirvana is not a dull contemplation of the nonobjective nothing, but an emotional accord filled with bliss deprived of any sensitive beginning. This is the sense of unity with the whole world of the live and dead (though, there is no such dichotomy in the state of nirvana), the world, where there is no individual consciousness as well. Consciousness as a light stream, flowing into the boundless ocean, becomes a part of the Whole Consciousness of a faithful Christian, feeling the presence of God, experiences the unlimited grace. Consciousness of Buddhist, deprived of any duality and any forms of categorization is disclosed as an unlimited peace and freedom, freedom from Karmic reincarnations and liberation from samsara. Consciousness of a scientist, having felt the temptation of nirvana (similar to bodhisattva, who remained in the world for the purpose of enlightenment of all living beings) and experienced the ineffability of the transpersonal experience, nevertheless, tries to "look into" all possible forms of the extraterrestrial essence, looking "inside oneself," inside his own consciousness.

15 The number of the thinkers, who wrote on spirituality, is innumerable. We pay tribute of respect and gratitude to them, but in the article written for the Russian psychologists we limited ourselves by a number of only Russian psychologists). 


\section{References}

Abaev, N.V. (1989). Čan'-Buddizm i kul'turno-psihologičeskie tradicii v srednevekovom Kitae [Chan-Buddhism and Cultural-Psychological Traditions in Medieval China]. Novosibirsk: Nauka.

Aldebill, M. (2006). Buddizm [The Buddhism]. Saint Petersburg: Piter.

Andresen, J., \& Forman, R. (Eds.). (2000). Cognitive Models and Spiritual Maps. Journal of Consciousness Studies. Special issue. 7 (11-12).

Androsov, V.N. (1990). Nagardžuna i ego učenie. [Nagarjuna and his study]. Moscow.

Androsov, V.N. (2001). Budda Šakâmini i indijskij buddizm. Sovremennoe istolkovanie drevnih tekstov [Buddha Shakyamuni and the Indian Buddhism. Modern Interpretation of Ancient Texts]. Moscow: Vostočnaâ literatura.

Asmolov, A.G. (1996). Kulturno-istoričeskâa psihologiâ i konstruirovanie mirov [Cultural-Historical Psychology and Construction of Worlds]. Moscow, Voronezh.

Aśvaghosa (1989) Šastra o probuždenii very v Mahaâne. [Shastra on Awakening of Faith in Mahayana. Translation by N.V. Abaev, Mahayana-shraddhotpada-shastra]. Čn'-Buddizm i kul'turno-psihologičeskie tradicii v srednevekovom Kitae (pp. 247-256). Novosibirsk: Nauka.

Ayusheva, D.V. (2003). Sovremennyj tibetskij buddizm na Zapade [Modern Tibetan Buddhism in the West]. Ulan-Ude: BNC SO RAN.

Bandler, R., \& Grinder, D. (1995). Šablony gipnotičeskih tehnik Miltona Eriksona s točki zreniâ NLP [Patterns of Hypnotic Techniques of Milton Erickson from the Point of View of NLP]. Moscow: NAPP.

Bergson, H. (1998). Tvorčeskâ̂ èvolùciâ [Creative Evolution]. Moscow: Kanon Press.

Bhikku Kvantipallo (2005). Sekrety meditacii [Secrets of Meditation]. Moscow: Belovod'e.

Bongard-Levin, G.M. (1980). Drevneindijskâ̂ civilizaciâ. Filosofiâ, nauka, religiâ [Ancient Indian Civilization. Philosophy, Science, Religion]. Moscow.

Borges, J.L. (1995). Vkus spaseniâ [The Taste of Salvation]. Kul'turno - Ékologičeskij žurnal Baikal. Ulan-Ude.

Chatterjee, A.K. (2004). Idealizm jogačary [Idealism of Yogochara]. Moscow: Centr buddologičeskih issledovanij "Šegen."

Choki Nima Rinpoche (2002). Edinstvo Mahamudry i Dzogčena [The Unity of Mahamudra and Dzhogchen]. Kazan: Blankizdat.

Cole, M. (1997). Kul'turno- istoričeskaâ psihologiâ. Nauka buduŝego [Cultural Psychology: A Once and Future Discipline]. Moscow. 
Dandaron, B.D. (1997). Pis'ma o buddijskoj ètike [Letters about the Buddhist Ethics]. Saint-Petersburg: Aletejâ.

Dhammapada (1991). Translation from Pali, introduction and comments by V.N. Toporov. Riga: UGUNS.

Elo Rinpoche (2006). Boevaâ čakra. Mahaânoskoe preobraženie myšleniâ. Kommentarii k tekstu Dharmarakšity. [Fighting Chakra. Mahayan Transformation of Thinking. Comments to the Text by Dharmarakshity]. Ulan-Ude: Rinpoche-Baksha.

Erickson, M. (2005). Moj golos ostanetsâ s vami [My Voice Remains with You]. Moscow.

Gostev, A.A. (1998). Doroga izzazerkalâ: psihologiâ razvitiâ obraznoj sfery čeloveka [Road from the Wonderland: Psychology of Development of the Figurative Sphere of a Man]. Moscow. Kaas.

Grinder, D., \& Bendler, R., (1995). Struktura magii [Structure of Magic]. Moscow:

Grof, S. (2002). Holotropnoe soznanie [The Holotropic Mind]. Moscow.

Gryazeva, V.A., \& Petrovsky, V.A. (1993). Odarennye deti: èkologiâ tvorčestva [Gifted Children: Ecology of Creativity]. Moscow.

Kharash, A.U. (1980). Princip deâtel'nosti v issledovanii mežličnostnogo vospriâtiâ [Principle of Activity in the Research of the Interpersonal Perception]. Voprosy psihologii, 3, 20-31.

Khoruzhy, S.S. (2000). Pravoslavnâ̂ askeza - klüč k novomu videniû čeloveka [Orthodox Ascesis - a Key to the New Vision of a Human]. Moscow: Omega.

James, W. (1993). Mnogoobrazie religioznogo opyta [The Varieties of Religious Experience]. Moscow.

Jampa Tinley (1995). Značenij mantry Buddy Šakâmuni “Om Muni Muni Maha Munie Suha" [Meaning of Mantras of Buddha Shakyamuni "Om Muni Muni Maha Munie Suha"] Kul'turno - Ékologičeskij žurnal Baikal. Ulan-Ude.

Jung, C.G. (1997). Sinhroničnost' [Synchronicity]. Moscow: Refl Buk.

Karitsky, I.N. (2002). Teoretiko-metodologičeskoe issledovanie socialnopsihologičeskih praktik [Theoretical-Methodological Research of Social-Psychological Practices]. Moscow, Chelyabinsk: Socium.

Khokhlov, V. (Ed.). (1998). Psihoterapiâ $i$ duhovnye praktiki. Podhod Zapada $i$ Vostoka k lečebnomu processu [Psychotherapy and Spiritual Practices. Approach of the West and the East to the Treatment Process]. Minsk: Vida-N.

Kozlov, V.V. (2005). Psihotehnologii izmenennyh sostoânij soznaniâ [Psychotechnologies of Changed States of the Conscience]. Moscow: Institut psihiatrii.

Kozlov, V.V., \& Maikov, V.V. (2000). Osnovy transpersonal'noj psihologii. Istoki, istoriâ, sovremennoe sostoânie [Fundamentals of Transpersonal Psychology. Origins, History, Modern Condition]. Moscow. 
Kucherenko, V.V., Petrenko, V.F., \& Rossokhin, A.V. (1998). Izmenennye sostoâniâ soznaniâ: psihologičeskij analiz [Altered States of Consciousness: Psychological Analysis]. Voprosy psihologii, 3, 70-78.

Kulpe, O. (1914). Sovremennaâ psihologiâ myšleniâ [Modern Psychology of Thinking]. Novye idei v filosofi, 16.

Leontiev, A.N. (1981). Problemy razvitiâ psihiki [Problems of Mentality Development]. Moscow: MGU.

Lossky, N.V. (1992). Učenie o perevoploŝenii. Intuitivizm [Study on Reincarnation. Intuitionalism]. Moscow: Progress.

Luria, A.R. (1968). Lekcii po obŝej psihologii [Lectures on General Psychology] Moscow: MGU.

Luz, W., \& Michaels, A. (2005). Iisus ili Budda. Žizn' i učenie v sravnenii [Jesus or Buddha. Life and Study in Comparison]. Moscow: Biblejsko-bogoslovskij institut sv. apostola Andreâ.

Mindell, A. (2004). Snovidenie v bodrstvovanii [Dream in Vigil]. Moscow.

Moacanin, R. (2004) Psihologiâ Unga i buddizm [Psychology of Jung and Buddhism]. Moscow, Saint-Petersburg.

Nu Sen-Ju (1970). Puteљеstvie v dalekoe proљloe [Traveling in Far Past]. In Tanskie novelly (VII- IX vv.). Moscow.

Nyanaponika (1994). Vnimatel'nost' kak sredstvo duhovnogo vospitaniâ (buddijskij metod satipatthana) [Attention as the Means of Spiritual Upbringing (Buddhist Method of Satipatthana)]. Meditation. Moscow: Olma-press.

Oldenburg, S.F. (1919). Žizn' Buddy [Life of Buddha]. Saint-Petersburg. (2nd publ. Novosibirsk, 1994.)

Ozhiganova, G.V. (2004). Istoriâ psihologii: konceptual'nye podhody i metody issledovaniâ [History of Psychology: Conceptual Approaches and Methods of Research]. Psihologičeskij žurnal, 25 (3), 5-17.

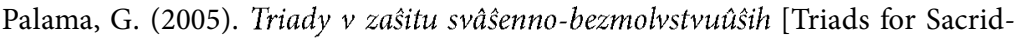
Silent]. Moscow: Canon+.

Paribok, A.V., \& Ehrman, V.G. (2003). Perevod i predislovie k "Džataki: izbrannye rasskazy o prošlyh žiznâh Buddy" [Translation and Foreword to "Dzhataki: Selected Stories about Previous Lives of Buddha"]. Saint-Petersburg.

Petrenko, V.F. (2002). Konstruktivistskaâ paradigma v psihologičeskoj nauke [Constructive Paradigm in the Psychological Science]. Psihologičeskij žurnal, 3, 113-121.

Petrenko, V.F., Kucherenko, V.V., \& Välbe, Y.A. (2006). Psihosemantika izmenennyh sostoânij soznaniâ [Psychosemantics of Altered States of Conscience]. Psihologičeskij žurnal, 5, 16-27.

Petrovsky, V.A. (1996). Ličnost' v psihologii [Personality in Psychology]. Rostovon-Don: Phoenix. 
Piatigorsky, A.M. (2004). Neprekraŝâ̂िijisâ razgovor, Lekcii po buddijskoj filosofii [Continuous Talk. Lectures on the Buddhist Philosophy]. Moscow: Azbuka-klassika.

Pomerants, G.S., \& Mirkina, Z.A. (2006). Velikie religii mira. [Great Religions of the World]. Moscow: Izdatel'skij dom Meždunarodnogo universiteta v Moskve.

Raikov, V.L. (1992). Gipnoz i postgipnotičeskaâ inerciâ kak model’ issledovaniâ tvorčestva [Hypnosis and Post-Hypnosis Inertia as the Model of Creativity Research]. Psihologičeskij žurnal, 3, 102-111.

Rosenberg, O.O. (1991). Trudy po buddizmu [Works on Buddhism]. Moscow.

Rubinstein, S.L. (1935). Osnovy psihologii [Foundations of Psychology]. Moscow.

Rudoy, V.I. (1990). Otečestvennaâ istoriko-filosofskaâ škola buddologii: vklad v problemu naučnogo istolkovaniâ buddijskih filosofskih tekstov [Domestic HistoricalPhilosophy School of Buddology: Contribution to the Problem of the Scientific Interpretation of Buddhist Philosophical Texts]. Buddizm. Problemy istorii, kultury, sovremennosti. Moscow.

Scherbatskoy, F.I. (1988). Izbrannye trudy po buddizmu [Selected Works on Buddhism]. Moscow.

Shestun, E.V. (2006). Pravoslavnye tradicii duhovno-nravstvennogo stanovleniâ ličnosti (istoriko-teoretičeskij aspekt) [Orthodox Traditions of the Spiritual-Moral Formation of a Personality (Historical-Theoretical Aspect)] (Candidate of Sciences dissertation). Kazan.

Shetok, I.H. (1994). Opyt vnimatel'nosti [Experience of Attention]. In Meditaciâ. Praktika buddijskogo metoda duhovnogo vospitaniâ. Moscow: Olma-Press.

Shkuratov, V.A. (1997). Istoričeskaâ psihologiâ [Historical Psychology]. Moscow: Smysl.

Strelkov, A.V., Torchinov, E.A., Mongush, M.V., \& Ryabov, S.V. (2006). Buddizm. Kanony, Istoriâ, Iskusstvo. Naučnoe izdanie [Buddhism. Canons, History, Art. Scientific edition]. Moscow: Dizajn, Informaciâ, Kartografiâ.

Subbotsky, E.V. (1983). Nravstvennoe razvitie doškol’nika [Moral Development of Children of Preschool Age]. Voprosy psihologii, 4, 29-38.

Toporov, V.N. (1991). Perevod s pali, vvedenie i kommentarii $k$ Džammapada [Translation from Pali, Introduction and Comments to Dhammapada]. Riga: Uguns.

Torchinov, E.A. (2005). Vvedenie v buddizm [Introduction to Buddhism]. SaintPetersburg: Amphora.

Tsybikov, G.T. (1991). Izbrannye trudy v dvuh tomah [Selected Works in Two Volumes]. Novosibirsk: Nauka.

Tulki Tondub Rinpoche (2006). Tajnye učeniâ Tibeta: ob"âsnenie tibetskoj buddijskoj tradicii terma [Secret Studies of Tibet: Explanation of Tibetan Buddhist Tradition of Terma]. Saint-Petersburg: Kul'turnyj centr "Uddiâna." 
Varela, F.J., \& Shear, J. (Eds.). (1999). The View from Within. First-Person Approaches to the Study of Consciousness. UK: Imprint Academic.

Vasilyuk, F.E. (1984). Psihologiâ pereživaniâ [Psychology of Experience]. Moscow: MSU.

Vasilyuk, F.E. (2005). Pereživanie i molitva. Opyt obŝsepsihologičeskogo issledovaniâ [Experience and Prayer. The Experience of General Psychological Research]. Moscow: Smysl.

Volkova, A.N. (2002). Fenomenologiâ mističeskogo opyta [Phenomenology of the Mystical Experience]. Saint-Petersburg.

Vygotsky, L.S., \& Luria, A.R. (1930/1993). Ėtûdy po istorii povedeniâ [Sketches on History of Behaviour]. Moscow: Pedagogika.

Wittgenstein, L. (2003). Âzyki kak obraz mira [Languages as the Image of the World]. Moscow.

Yarbus, A.L. (1965). Rol' dviženiâ glaz v processe zreniâ [Role of Eyes Movement in the Process of Vision]. Moscow: Nauka.

Zinchenko V.P., \& Vergiles, N.Yu. (1969). Formirovanie zritel'nogo obraza [Formation of the Visual Pattern]. Moscow: MGU. 